\title{
Perceptions Regarding Cheating among CM and AEC Students
}

\section{Dr. Gouranga Banik, Tennessee State University}

\section{Gouranga Banik, Ph.D., P.E., PMP., F.ASCE}

Currently Gouranga Banik is the departmental chair and professor of Civil and Architectural Engineering at Tennessee State University. Dr. Banik completed his Ph.D. in Civil and Construction Engineering from Iowa State University. He has eleven years working experience in both private and public sector as an engineer and/or project manager. He is a registered professional engineer and certified project manager (PMP). Dr. Banik has more than forty refereed publications in the area of civil engineering and construction management. He presented some of his research in several well-known and peer reviewed conferences like ASEE, ASCE, ASC, WEFTEC and CIB, and published articles in those conference proceedings. He presented his research all over the world including the United States, Canada, Greece, Italy, Brazil and the Philippines. 


\section{Perceptions Regarding Cheating among CM and AEC Students}

Introduction

From the existing research, it is understood that that academic cheating has become increasingly prevalent at all levels of education, from elementary school through graduate school (McCabe, Treviño, \&Butterfield, 2006). A number of studies have explored the prevalence, determinates, and different definitions of cheating behavior (Carpenter et. al. 2006, Atschular, 2001). A historical comparison shows that in 1969, 33\% of high school students cheated in their academic work compared to $67.8 \%$ in 1999 (Altschuler, 2001). In the universities, there is evidence that the percentage of students who cheat while remained constant over time-82\% in 1963 versus $84 \%$ in 1993, but the severity of cheating in terms of frequency and types of dishonesty increased significantly. Students who admit to having cheated in an exam increased from $26 \%$ in 1963 to $54 \%$ in 1993, and the percentages of students who engaged in appropriate collaboration with other students on homework assignments increased from $11 \%$ to $49 \%$ (Passow et. al., 2006). It can be due to increase of using collaborations in the classes. Several studies have identified variations in rates of cheating among students within different majors. With general agreement among these studies that higher percentages of business and engineering students engage in cheating which are $91 \%$ and $82 \%$ respectively compared to students in the social and natural sciences which are 73\% and 71\% respectively (McCabe, 1997, Mattei, 2008). Likewise, past research has identified that variations in rates of cheating among university students from different countries and between genders, with statistically significant differences between students from Japan, the United States, the United Kingdom, and South Africa (Whitely, 1999).

Like other professions, lack of ethics or improper implementation of ethics is becoming widespread problems among all professions including architecture, engineering and construction (AEC). It can be due to widespread availability of materials through web and/or lack of understanding the importance of ethics as a professional responsibility (Banik, 2010). There can be many reasons for student cheats including due to the poor preparation of faculty for the class and/or can be inadequate academic preparation of students. In a recent survey commissioned by Knowledge Ventures, an education integrity is an issue on their campus but unable to pinpoint the extent of the problem, the source of the problem, or whether specific disciplines or groups of students were more at risk. In addition of those who said academic integrity is an issue, 83 percent said that it has become more of an issue over last several years-primarily widespread use of internet as a research tool (Pricewater Cooper study, 2001). Academia is struggling to understand what is happening and why? Which of the usual explanations for academic dishonesty apply? Lack of clarity of plagiarism in our learning environment? Lack of clear position on the instructor's part? Lack of personal connection in the larger class? Although most of the students understand that downloading an essay and submitting it as his own an unethical act but still students do- but why? Lack of enforcement or lack of serious punishment? Whatever reasons are, cheating will not be minimized unless root cause can be found and addressed in a proper way in all intuitions rather than a single institution (Banik, 2010). To answer these questions, a detailed questionnaire was designed and developed based on PACES-1 survey for both construction management and AEC students. For this article, AEC students included students of CM, CE, CET, Architecture and construction engineering. 
Different forms of plagiarism in higher education

Before addressing the concerns, a thorough literature survey was conducted to understand what is cheating or what does it really mean? Hannabuss (2001) defined plagiarism as 'the unauthorized use or close imitation of the ideas and language/expression of someone else' and then the representation of this work as the plagiarist's own In the context of university education, however, plagiarism does not have a single meaning and can range from the citation of a few sentences without attribution through to the copying out of an entire manuscript. Myers (1998) noted how plagiarism in the academic world 'exists not in law as copyright does, but as institutional rules and regulations’. Hence, conventions relating to what does and does not constitute plagiarism are formulated and interpreted differently across institutions. Nevertheless, common themes emerge in most expositions of the construct, usually involving the notions of intent, deliberate deception and failure to acknowledge sources (see Larkham \& Manns, 2002).

As plagiarism covers a sizeable continuum ranging from 'sloppy paraphrasing to verbatim transcription with no crediting of the source' (Larkham \& Manns, 2002). 'Minor plagiarism’ has been stated to comprise activities such as cutting and pasting relatively small amounts of material from web pages without acknowledgement (Davis, 1992), the reproduction of a sentence or two without quotation marks and without a citation (Standler, 2000), paraphrasing without references, and inventing fictitious references (Bjorklund \& Wenestam (1999). Major plagiarism, according to Standler (2000) occurs when 'a significant fraction of the entire work was written by someone else'. Standler (2000) noted however that there was no legal distinction between major and minor forms of plagiarism. This was unfortunate, Standler (2000) continued, because differences in the penalties imposed for various levels of plagiarism could be very large, ranging from a mild rebuke to permanent exclusion from an institution. Another explanation for researchers' interest in the distinction between major and minor plagiarism has been the observation of a substantially greater willingness among students to perpetrate minor as opposed to major plagiarism (see Kuehn et al., 1990; Franklyn-Stokes \& Newstead, 1996; McCabe \& Trevino, 1996; Newstead et al., 1996; Bjorklund \& Wenestam, 1999; Davis, 1992). Possibly, students' internal rationales for committing serious acts of academic dishonesty differ from those resulting in minor offences (Kuehn et al., 1990). Bjorklund and Wenestam (1999) suggested that minor plagiarism tended to be far more 'opportunistic in nature than deliberately planned.

The outcome of cheating may be a critical factor in gaining a more complete understanding of how students cheat and why. It may be important to distinguish instances in which cheating has led to increased performance from instances where cheating was not successful and how this may moderate students' attitudes and behaviors toward others who cheat. Most university professors discourage students from engaging in plagiarism on the grounds that the practice is fraudulent and deceptive, involves the theft of intellectual property, and 'conceals and misrepresents the originality of the true author' (Clough, 2003).

This article is based on a study conducted in a university for the Departments of Civil Engineering, Civil Engineering Technology, Architecture and Construction Management at SPSU. The main objective of this is to find the perception of AEC and CM students: is it prevalent like other majors or different? Is there any difference of opinion CM education compared with the AEC education although these disciplines are closely aligned. 


\section{Questionnaire Survey}

To understand the trend and perceptions of cheating for the AEC students, a detailed questionnaire survey was conducted in a university. The questionnaire was designed based on PACES-1 study (Carpenter et. al. 2006) so that the data can be used for comparison purposes. Altogether two hundred fifty two students responded. Among them, one hundred ninety two students are from Construction Management, twenty one students are from Civil Engineering Technology (CET), sixteen students are from Civil Engineering, five students are from Construction Engineering, twelve students are from architecture and six are others. For this article, only data from construction management (183) students were analyzed compared with the total AEC students' respondents (246) except the others.

\section{Results and Discussions}

From Table 1, one hundred eighty three CM students responded regarding attitude toward cheating and one hundred thirty two students responded regarding frequency of cheating either 0 time or one to two times, or equal or more than three times.

Copying from another student during a test or a quiz: One hundred sixty nine construction management students out of one hundred eighty three (92.3\%) students believed copying from another students during a test or quiz is cheating compared to two hundred thirty out of two hundred forty six (93.5\%) all AEC students. It indicated that majority of the students agreed with the statement but about six percent of students under neither category. It can be due to to close alignment of the professions.

Permitting another student to look at your answer during a quiz or exam: When the responses are looked, about $81 \%$ CM students felt that permitting another student to look the answer is cheating compared to $75 \%$ of AEC students. It might indicate that CM students are probably little bit more lenient about cheating.

Asking another student about questions on an exam you have not yet taken: About 33\% of both CM and AEC students felt that asking questions about the exam which was not taken was cheating. $67 \%$ thought negative probably because anyway they need to study the materials.

Delaying taking an exam or turning in a paper later with a false excuse: Looks like false excuse for taking late exam or late submission of homework are acceptable among both CM and AEC students. About77\% of CM and 72\% AEC students think that both the groups will use false excuses if they were delay in completing the homework or late in tests.

Table 1: Students’ attitudes regarding cheating 


\begin{tabular}{|c|c|c|c|c|c|c|}
\hline & \multicolumn{2}{|c|}{ 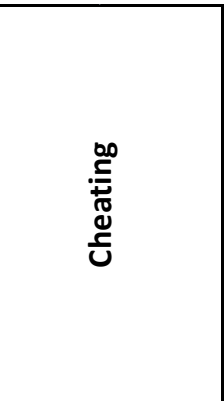 } & \multicolumn{2}{|c|}{ 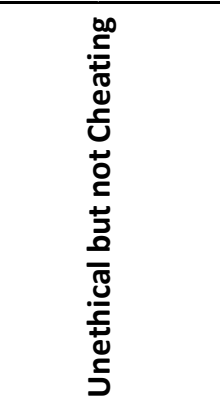 } & \multicolumn{2}{|c|}{ 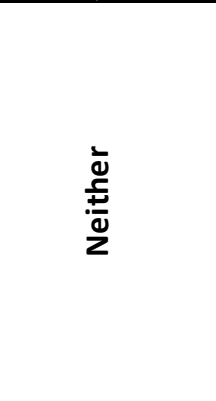 } \\
\hline & CM- & ALL & $\mathrm{CM}$ & All & $\mathrm{CM}$ & ALL \\
\hline & 183 & 246 & 183 & 246 & 183 & 246 \\
\hline Copying from another student during a test or a quiz & 169 & 230 & 2 & 1 & 12 & 15 \\
\hline $\begin{array}{l}\text { Permitting another student to look at your answer during a } \\
\text { quiz or exam }\end{array}$ & 148 & 185 & 23 & 41 & 12 & 20 \\
\hline $\begin{array}{l}\text { Asking another student about questions on an exam you } \\
\text { have not yet taken }\end{array}$ & 60 & 81 & 85 & 112 & 38 & 53 \\
\hline $\begin{array}{l}\text { Delaying taking an exam or turning in a paper later with a } \\
\text { false excuse }\end{array}$ & 43 & 70 & 114 & 146 & 26 & 30 \\
\hline $\begin{array}{l}\text { Copying from an unapproved reference sheet during a closed } \\
\text { book test or quiz }\end{array}$ & 151 & 201 & 15 & 26 & 17 & 19 \\
\hline $\begin{array}{l}\text { Claiming to have handed in an assignment to exam when you } \\
\text { did not }\end{array}$ & 87 & 133 & 76 & 89 & 20 & 24 \\
\hline Taking an exam for another student & 121 & 205 & 37 & 27 & 25 & 14 \\
\hline $\begin{array}{l}\text { Working in groups on assignments when there is no class } \\
\text { policy on group work }\end{array}$ & 31 & 55 & 42 & 60 & 110 & 131 \\
\hline $\begin{array}{l}\text { Adding fake references to term papers to expand } \\
\text { bibliography }\end{array}$ & 85 & 123 & 75 & 95 & 23 & 28 \\
\hline $\begin{array}{l}\text { Copying an old term paper or lab-report from a a previous } \\
\text { year }\end{array}$ & 93 & 142 & 52 & 62 & 38 & 42 \\
\hline Studying from other students for a test & 31 & 63 & 41[ & 52 & 111 & 131 \\
\hline $\begin{array}{l}\text { Copying another students homework when it is not } \\
\text { permitted by the instructor }\end{array}$ & 133 & 197 & 23 & 29 & 27 & 20 \\
\hline $\begin{array}{l}\text { Copying a passage out of a textbook for homework } \\
\text { assignments }\end{array}$ & 58 & 85 & 57 & 70 & 68 & 91 \\
\hline $\begin{array}{l}\text { Submitting or copying homework assignments from a } \\
\text { previous term }\end{array}$ & 82 & 135 & 51 & 68 & 50 & 43 \\
\hline $\begin{array}{l}\text { Witnessing a case of cheating in a class and not reporting it to } \\
\text { the instructor }\end{array}$ & 35 & 59 & 87 & 121 & 61 & 66 \\
\hline $\begin{array}{l}\text { Storing answers to a test/homework after it was graded and } \\
\text { telling the }\end{array}$ & 115 & 139 & 32 & 59 & 36 & 48 \\
\hline $\begin{array}{l}\text { Changing the answers on your test in a calculator or Personal } \\
\text { Digital Assistant (PDA) }\end{array}$ & 129 & 183 & 21 & 31 & 33 & 32 \\
\hline Paying someone else to take an exam/write a paper for you & 140 & 179 & 30 & 44 & 13 & 23 \\
\hline Working in groups on Web-based quizzes & 73 & 104 & 58 & 77 & 52 & 65 \\
\hline Working in groups on take-home exams & 63 & 94 & 63 & 82 & 57 & 70 \\
\hline
\end{tabular}


Copying from an upapproved reference sheet during a closed-book test or quiz: About $83 \%$ of CM students felt that copying from an unapproved reference is cheating compared with $82 \%$ of AEC students.

Claiming to have handed in an assignment or exam when you did not: $48 \%$ of CM students think that it is cheating compared with $54 \%$ of AEC students.

Taking an exam for another student: $66 \%$ of CM students think that taking an exam from another students is cheating compared with $83 \%$ of AEC students. When all the data were looked, the author did not find any reason for this kinds of variations.

Working in groups on assignments when there is no class policy on group work: A smaller percentages of both CM and AEC students think that it is unethical. Sixty percents of CM students thinks that it is not cheating compared with 53\% of AEC students.

Adding fake references to term papers to expand bibliography: About 46\% of CM students thought that fake reference is cheating compared with 50\% of AEC students.

Copying an old term paper or lab-report from a previous year: 51\% of CM students thought that copying from old term paper or lab report was cheating compared with 58\% of AEC students.

Studying from other students for a test: Only limited number of students thought that studying from other students work was cheating. It might happen due to the recent encouragement of team works across the curriculum.

Copying another student's homework when it is not permitted by the instructor: About $73 \%$ of CM students expressed that copying from another students $\mathrm{HW}$ is cheating compared with $80 \%$ of AEC students.

Copying a passage out of a textbook for homework assignments: About $73 \%$ of CM student's belief that it was cheating compared with $81 \%$ of AEC students. The results indicated that AEC students are more ethical that CM students in this questions.

Witnessing a case of cheating in a class and not reporting it to the instructor: Only 19\% of CM student's belief that it is not ethical compared with $24 \%$ of AEC students. It could be due to the lack of understanding of their ethical responsibilities.

Changing the answers on your test in a calculator or Personal Digital Assistant (PDA): About $70 \%$ of CM students thought it was cheating compared with 74\% of AEC students.

Paying someone else to take an exam/write a paper for you: About $77 \% \mathrm{CM}$ students think that paying someone to write a paper or take the exam is not acceptable idea compared with $73 \%$ of AEC students. 
Working in groups on Web-based quizzes: About $40 \%$ of CM students thought it is not ethical to work in groups for a online quizzes compared with $42 \%$ of AEC students. Online education can be a problem if student take their quizzes in a group format.

Working in groups on take-home exams: There is no clear distinction either it is ethical or not ethical or neither for both CM and AEC students.

\section{Conclusions}

From the above Table and discussions, it is evident that both the construction management and AEC students have similar kind of attitudes regarding most of the questions regarding cheating. It can be due to the similar courses they usually take or can be due to their similar academic background nad/or nature of course works. In few cases, there is a difference of opinion between this groups which can be due to inclusion of engineers and architectures in AEC who might have better appreciation regarding professional ethics.

\section{Future Study}

The remaining data will be analyzed to find the perceptions based on the grades, working or nonworking students, families of higher or low income and the others, and publish the results in the next annual conference. Also the author would like to develop a questionnaire for the students to understand what should be done in classroom to minimize and/or prevent these problems based on the outcome of this study.

References

1) Altschuler, GC. "Batting the cheats. Education Life Supplemental. New York Times. Sunday, Jan 7, 2001, section 4A, Page 15, Column1.

2) Banik, G. C. "Ethics: Why and how it can be Taught for Engineering and Construction Students." Presented and published in 2011 ASEE annual conference, Architectural Engineering Division, Vancouver, Canada, June 2011.

3) Bjorklund, M. \& Wenestam, C. (1999) Academic cheating: frequency, methods and causes, Proceedings of the 1999 European Conference on Educational Research, Lahti, Finland. Available online at: www.leeds.ac.uk/educol/documents/00001364.htm.

4) Clough, P. Old and new challenges in automatic plagiarism detection (Sheffield, Plagiarism Advisory Service, University of Sheffield), 2003.

5) Davis, S.F., Grover, C.A., Becker, A.H. and McGrove, L.N. “Academic dishonesty: Prevalence, determinants, techniques, and punishments. Teaching of Psychology 19(1):16-120, 1992.

6) Franklyn-Stokes, A., and S. E. Newstead. Individual differences in student cheating. Journal of Educational Psychology 88:229-42, 1996.

7) Hardigan, Patrick. “ First and Third-Year Pharmacy Students’ Attitudes towards Cheating Behaviors”. American Journal of Pharmaceutical Education, 68(5), article 110, 2004.

8) Harris, C.E., M. Davis, M.S. Pritchard, and M.R. Rabins, "Engineering Ethics: What? Why? How? and When?” Journal of Engineering Education, Pp. 93-96, 1996. 
9) Carpenter, Don., Harding, T and et al, “Engineering Students' Perceptions of and Attitudes Towards Cheating”. Journal of Engineering Education, Pp. 181-194, 2006.

10) Kuehn, P., Stanwyck, D. \& Holland, C. Attitudes toward cheating behaviours in the ESL classroom, TESOL Quarterly, 24(2), 313-317, 1990.

11) Larkham, P.J. and Manns, S. "Plagiarism and its treatment in higher education”. J. of Further and Higher Education, Vol. 26, Issue 4., 2002.

12) Mattei, N., "Comparison of cheating behaviors in undergraduate engineering students and the general student population at the University of New Orleans", ASEE Annual Conference, Pittsburgh, Pennsylvania: American Society of Engineering Education, 2008.

13) McCabe, D.L. “Classroom cheating among natural science and engineering majors.” Science and Engineering Ethics. 3: 433-445. 1997.

14) McCabe, D. L., Treviño, L. K., \& Butterfield, K. D. Academic dishonesty in graduate business programs: Prevalence, causes, and proposed action. Academy of Management Learning \& Education, 5, 294-305, 2006.

15) Michael Davis, "Thinking Like an Engineer: the Place of a Code of Ethics in the Practice of a Professional," Philosophy and Public Affairs 20, pp. 150-167, spring 1991.

16) Michael S. Pritchard, ed., "Teaching Engineering Ethics: A Case Study Approach,” NSF Grant No. DIR 8820837. Available through the Center for the Study of Ethics in Society, Western Michigan University, Kalamazoo, MI 49008-5022.

17) Myers, S. Questioning author(ity): ESL/EFL, science and teaching about plagiarism, TESL-EJ, 3(2), 11-20, 1998.

18) Nonis, S., and C.O.Swift, "An examination of the relationship between academic dishonesty and workplace dishonesty: A multicampus investigation.” Journal of Education for Business. 77(2), 69-77, 2001.

19) Passow, H.J., M.J. Mayhew, C.J. Finelli, T.S. Harding, and D.D. Carpenter," Factors influencing engineering students' decisions to cheat by type of assessment", Research in Higher Education Vol. 47, No. 6, pp. 643-684, 2006.

20) Sims, R.L. “ The relationship between academic dishonesty and unethical business practices.” Journal of Education for Business. 68(4), 207-211, 1993.

21) Standler, R. (2000) Plagiarism in colleges in the USA. Available online at: www.rbs2.com/plag.htm

22) Whitley, B.E.," Gender differences in cheating attitudes and classroom cheating behavior: A meta analysis", Sex Roles Vol. 41, No. 9/10, pp. 657-680. 1999. 